\title{
Tomato Hornworm Manduca quinquemaculata (Haworth) (Insecta: Lepidoptera: Sphingidae) ${ }^{1}$
}

\author{
Morgan A. Byron and Jennifer L. Gillett-Kaufman²
}

\section{Introduction}

The tomato hornworm, Manduca quinquemaculata (Haworth), is a common garden pest that feeds on plants in the Solanaceae (nightshade) family including tomato, peppers, eggplant, and potato. The adult form of the tomato hornworm is a relatively large, robust-bodied moth, commonly known as a hawk moth or sphinx moth. The adult moth feeds on the nectar of various flowers and, like the larval form, is most active from dusk until dawn (Lotts and Naberhaus 2017). The tomato hornworm (Figure 1) may be confused with the tobacco hornworm, Manduca sexta (L.) (Figure 2), a closely related species that also specializes on solanaceous plant species and is similar in appearance. Various morphological features can be used to differentiate these hornworms, namely that tomato hornworm has V-shaped yellow-white markings on the body and the tobacco hornworm has white diagonal lines. Additionally, the horn, a small protrusion on the final abdominal segment of the caterpillar that gives the hornworm its name, of the tomato hornworm is black, whereas the horn of the tobacco hornworm is reddish in color.

\section{Distribution}

The tomato hornworm has a wide distribution in North America and can be found from northern Mexico to the southernmost region of Canada, though it is not evenly distributed throughout this range (Lotts and Naberhaus 2017; Bossart and Gage 1990). The tomato hornworm is uncommon in the Southeast and is replaced by the tobacco hornworm in this region. In Florida, hornworm damage on tomato is typically caused by the tobacco hornworm, rather than the tomato hornworm, despite its common name.

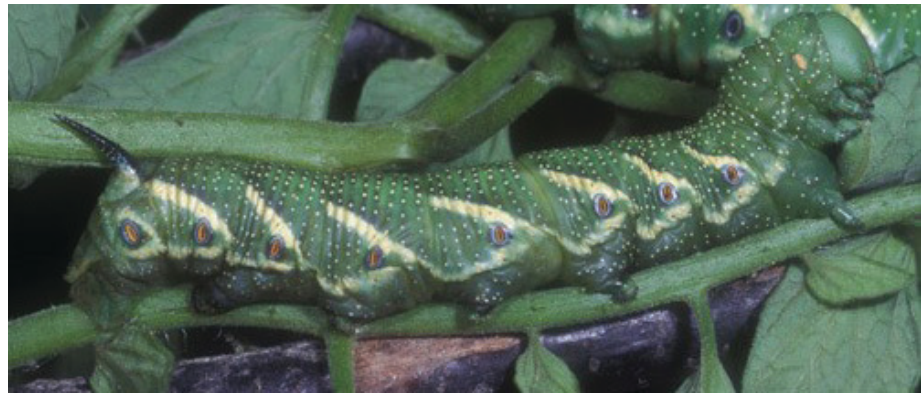

Figure 1. Late instar larva of the tomato hornworm, Manduca quinquemaculata (Haworth). Credits: Paul Choate, UF/IFAS

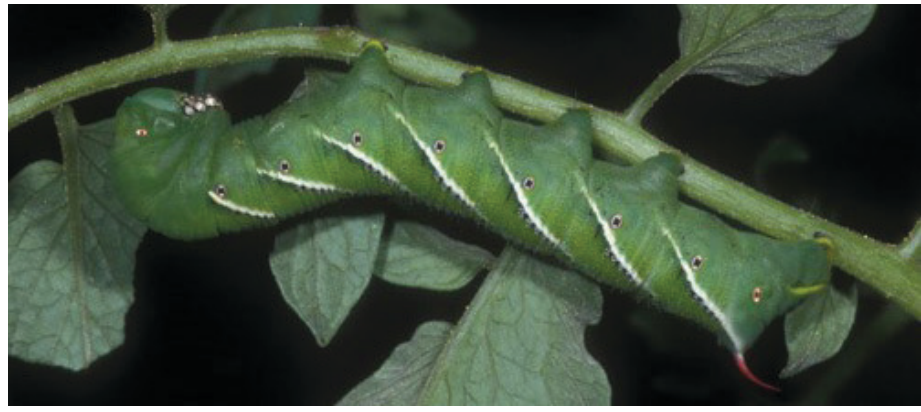

Figure 2. Late instar larva of the tobacco hornworm, Manduca sexta (L.).

Credits: James Castner, UF/IFAS

1. This document is EENY700, one of a series of the Department of Entomology and Nematology, UF/IFAS Extension. Original publication date January 2018. Visit the EDIS website at http://edis.ifas.ufl.edu. This document is also available on the Featured Creatures website at http://entnemdept.ifas.ufl. edu/creatures/.

2. Morgan A. Byron; and Jennifer L. Gillett-Kaufman, associate Extension scientist, Department of Entomology and Nematology; UF/IFAS Extension, Gainesville, FL 32611.

The Institute of Food and Agricultural Sciences (IFAS) is an Equal Opportunity Institution authorized to provide research, educational information and other services only to individuals and institutions that function with non-discrimination with respect to race, creed, color, religion, age, disability, sex, sexual orientation, marital status, national origin, political opinions or affiliations. For more information on obtaining other UF/IFAS Extension publications, contact your county's UF/IFAS Extension office. 


\section{Description}

\section{Eggs}

After emergence, the adult moths mate and females deposit eggs singly on the solanaceous host plant during the evening. Eggs are small ( $\sim \mathrm{mm}$ in diameter) and green to yellow-green with a pearly appearance (Cranshaw 2004).

\section{Larvae}

Once they have eclosed from the egg, first instar larvae do not move away from the leaf onto which their egg was laid. They feed on the leaf tissue, molting into second instar larvae (Kessler and Baldwin 2002). In general, larvae do not move from the host plant until they reach the fifth instar; however, they are capable of migrating from their original host plant if there is no more food available (Kessler and Baldwin 2002).

Tomato hornworms are well camouflaged among the leaves of their host plants. Each instar is successively larger than the last, but otherwise they are very similar in appearance: the body is green with a blackish horn protruding from the posterior-most abdominal segment, and a series of white V-shaped markings along the sides of the body.

\section{Pupae}

The tomato hornworm creates a small space underground to pupate. The pupa (Figure 3 ) is relatively large, dark reddish-brown, and characterized by a maxillary loop at one end, which encases the mouthparts of the developing adult moth.

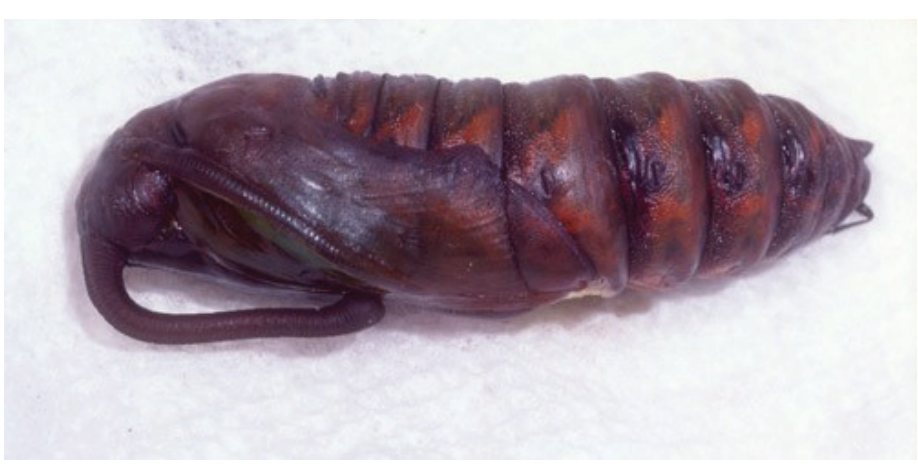

Figure 3. Pupa of Manduca quinquemaculata (Haworth). Credits: Paul Choate, UF/IFAS

\section{Adults}

Adults of the tomato hornworm are commonly referred to as five-spotted hawkmoths (Figure 4), referring to the pairs of orange-yellow markings along the sides of the abdomen. These moths are heavy-bodied and relatively large, though they are very capable flyers. Their graceful, agile flying behavior and overall body shape is reminiscent of a hummingbird, and moths in the Sphingidae family are sometimes referred to as hummingbird moths (Cranshaw 2004). The adult moths nocturnally visit flowers, feeding on nectar.

The five-spotted hawkmoth (Figure 4) can be distinguished from the Carolina sphinx moth (the adult form of the tobacco hornworm) (Figure 5) by counting the pairs of yellowish-orange markings on the grayish abdomen: the five-spotted hawkmoth has five and the Carolina sphinx moth typically has six. The wings of both are an overall mottled pattern of gray, white, and brown resembling tree bark, with the forewings much larger than the hind wings. The five-spotted hawk moth tends to have lighter coloration on the hindwings than the Carolina sphinx moth, though variation in adult coloration may occur.

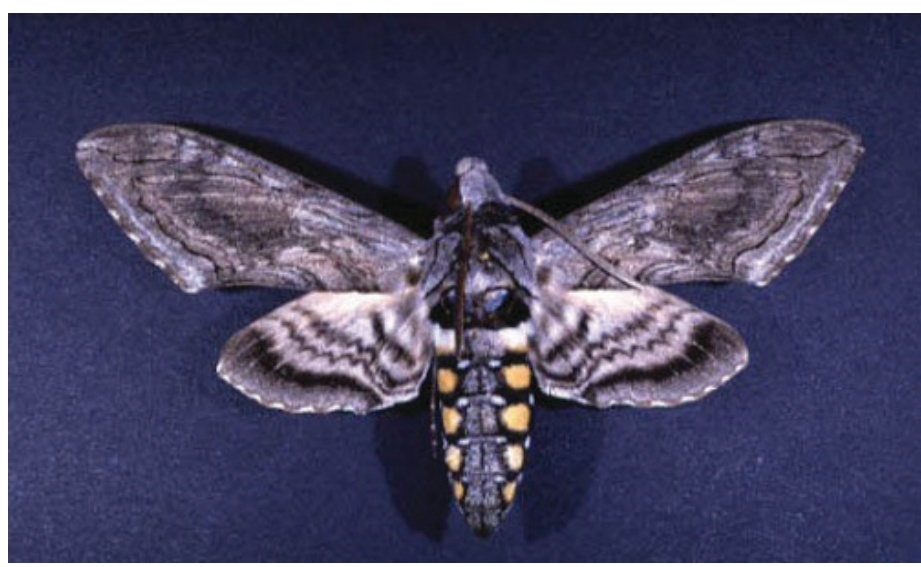

Figure 4. Adult form of Manduca quinquemaculata (Haworth), a sphinx moth sometimes called the five-spotted hawkmoth.

Credits: John Capinera, UF/IFAS

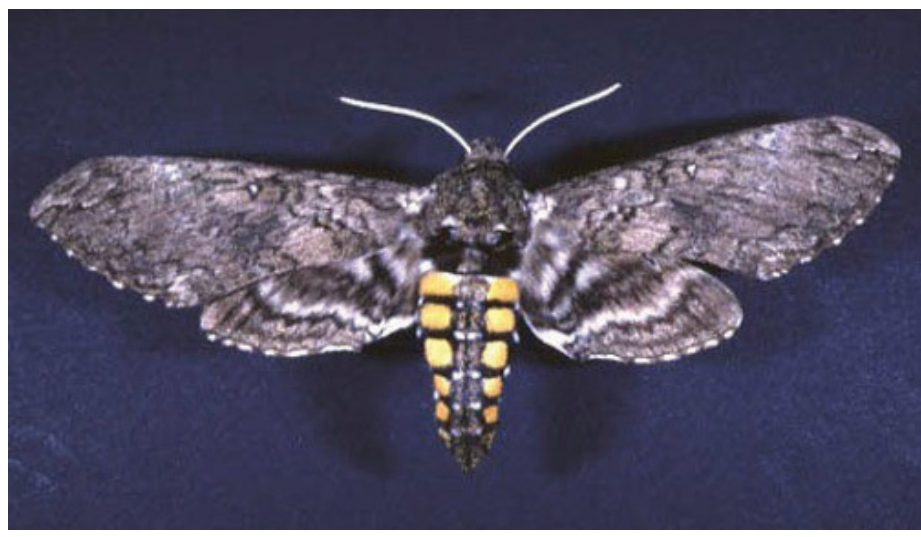

Figure 5. Adult form of Manduca sexta (L.), a sphinx moth sometimes called the Carolina sphinx moth.

Credits: John Capinera, UF/IFAS

\section{Host Plants}

Wild tobacco, Nicotiana attenuata, is most likely the primary host plant of the tomato hornworm (Kessler and Baldwin 2002). However, these caterpillars are also known to feed on crops in the family Solanaceae and can 
sometimes become economically important pests of such crops including tomato, pepper, tobacco, eggplant, and potato. Additionally, many common and widely distributed weeds, like jimsonweed (Datura stramonium), are suitable hosts in this family.

\section{Damage}

Damage to crops or garden plants is caused by the larval stage of the tomato hornworm. As they mature, hornworm caterpillars are known to feed continuously on their host plants, not moving far from the original site of oviposition (Kessler and Baldwin 2002). Tomato hornworms begin feeding higher in the canopy of the plant and can eventually cause complete defoliation if they are not removed (WoldBurkness and Hahn 2017). These caterpillars have also been known to feed on green, developing fruit, especially those of their preferred cultivated host, tomato (Wold-Burkness and Hahn 2017). Fruit that has been fed on by hornworms will not mature properly and has no market value.

\section{Management}

Tomato hornworms are typically easy to control in a home garden through regular monitoring of plants for presence of caterpillars, defoliation, or fruit damage. Removing caterpillars by hand is often an effective means of control, but insecticides are available if hand picking is not practical. Bacillus thuringiensis (Bt), a biological insecticide, is a widely available organic option for control of caterpillars. Caterpillars must ingest the $\mathrm{Bt}$ for it to be effective. Multiple applications may be necessary, as Bt can be washed from the plants by rainfall or irrigation water. Always follow label instructions and monitor plants for damage after application of any insecticide.

Cultural controls for tomato hornworm include management of solanaceous weed species, encouraging populations of natural enemies, and crop rotation. Tillage of solanaceous crop fields can destroy the pupal stage of the hornworm, preventing adult emergence and disrupting the moth's life cycle (Wold-Burkness and Hahn 2017).

Florida Insect Management Guide for tomatoes, peppers, and eggplant

\section{Selected References}

Bossart JL, Gage SH. 1990. "Biology and seasonal occurrence of Manduca quinquemaculata and M. sexta (Lepidoptera: Sphingidae) in southwestern Michigan." Environmental Entomology 19: 1055-1059.
Cranshaw W. 2004. "Hornworms/Sphinx moths." Garden Insects of North America: The Ultimate Guide to Backyard Bugs. Princeton, NJ: Princeton University Press.

Kessler A, Baldwin IT. 2002. "Manduca quinquemaculata's optimization of intra-plant oviposition to predation, food quality, and thermal constraints." Ecology 83: 2346-2354.

Lotts K, Naberhaus T. (2017). "Five-spotted hawkmoth, Manduca quinquemaculata (Haworth 1803)." Butterflies and Moths of North America. http://www. butterfliesandmoths.org/ (1 October 2017)

Wold-Burkness S, Hahn J. (2017). Tomato hornworms in home gardens. University of Minnesota Extension. (1 October 2017) 